\title{
Effect of Quenching Temperature on Microstructure and Rolling Contact Fatigue Behavior of 17Cr2Ni2MoVNb Steel
}

\author{
Yalong Zhang 1,2,3, Shengguan Qu 1,2,3,*(D), Fuqiang Lai ${ }^{1,2,3}$, Haidi Qin ${ }^{1,2,3}$, Liman Huang ${ }^{1,2,3}$ \\ and Xiaoqiang $\mathrm{Li}^{1,2,3}$ \\ 1 Guangdong Key Laboratory for Advanced Metallic Materials Processing, \\ South China University of Technology, Guangzhou 510640, China; zhanglong_china@126.com (Y.Z.); \\ lfq0623@163.com (F.L.); 15914445865@163.com (H.Q.); nn_huangliman@163.com (L.H.); \\ lixq@scut.edu.cn (X.L.) \\ 2 National Engineering Research Center of Near-Net-Shape Forming for Metallic Materials, \\ Guangzhou 510640, China \\ 3 School of Mechanical and Automotive Engineering, South China University of Technology, \\ Guangzhou 510640, China \\ * Correspondence: qusg@scut.edu.cn; Tel.: +86-020-8711-1983
}

Received: 28 August 2018; Accepted: 17 September 2018; Published: 19 September 2018

check for updates

\begin{abstract}
Cr2Ni2MoVNb steel is a new type of gear steel in the automotive industry; the rolling contact fatigue behavior is not well documented. In this study, some microscopic analysis methods (optical microscope (OM), scanning electron microscope (SEM), transmission electron microscope (TEM), X-ray diffractometer (XRD), and energy dispersive X-ray analysis (EDS)) were used to characterize material microstructure and damage surface. In addition, rolling contact fatigue behavior was evaluated by Weibull curve. The results show that the size of austenite grain increased while the quenching temperature increased. Moreover, the samples with a quenching temperature of $1000{ }^{\circ} \mathrm{C}$ exhibited the maximum mean life of $7.33 \times 10^{5}$ cycles. In addition, the failure mode of quenched at $900{ }^{\circ} \mathrm{C}$ and $1100{ }^{\circ} \mathrm{C}$ were delamination, and pitting was the main failure mode of $1000{ }^{\circ} \mathrm{C}$.
\end{abstract}

Keywords: $17 \mathrm{Cr} 2 \mathrm{Ni} 2 \mathrm{MoVNb}$; microstructure; quenching temperature; rolling contact fatigue

\section{Introduction}

Rolling contact fatigue (RCF) is a typical failure mode in the application of gears. Surface damage is a very complex phenomenon and the contact fatigue plays a fundamental role in the damage process [1]. The fatigue damages are influenced by various factors, including the lubrication oil, surface roughness, and mechanical properties of materials [2-5]. Numerous studies have focused on different heat treatment processes to improve mechanical properties in Fe-based alloys [6,7]. Long [8] investigated the effect of quenching temperature on martensite multi-level microstructure and properties of strength and toughness in 20CrNi2Mo steel and found that the impact toughness and fracture toughness increase by $32.4 \%$ and $27.8 \%$ with increasing of the quenching temperature, respectively. The early work by Matlock [9] indicated that the grain size is the most important factor affecting fatigue behaviors. Ma [10] determined the fatigue resistance is affected by plastic deformation under different slip ratio conditions. Wang [11] explored a coupling relationship between fatigue cracks and wear in curve track. Gallo [12] studied the relationship between roughness and fatigue characteristics of $40 \mathrm{CrMoV} 13.9$ notched components, with the most evident improvement being registered for the value of $\mathrm{Ra}=0.15 \mu \mathrm{m}$. 
To estimate the fatigue life, RCF test data of materials should be analyzed by a probabilistic approach. Yu [13] used the Weibull distribution diagram to analyze the rolling contact fatigue life of the Fe-Cr coating. Glover [14] studied the Weibull curve of fatigue life conform to the test results by ball-on-rod tester. The main purpose of this study is to demonstrate the effect of quenching temperature on microstructure and RCF behavior while using a self-designed rolling contact fatigue testing device. In this paper, these properties, in addition to damage mechanism and RCF cracks, are discussed.

\section{Experimental Procedure}

The chemical compositions of $17 \mathrm{Cr} 2 \mathrm{Ni} 2 \mathrm{MoVNb}$ steel are presented in Table 1 and they were prepared by the sequential processes of melting in an electric furnace-ladle refining-vacuum degassing, then continuous rolling into a $\varphi 100 \mathrm{~mm}$ round bar. This was followed by quenching at different temperatures and tempering at $180^{\circ} \mathrm{C}$ for $2 \mathrm{~h}$, as shown in Table 2 .

Table 1. Chemical compositions of $17 \mathrm{Cr} 2 \mathrm{Ni} 2 \mathrm{MoVNb}$ steel (wt. \%).

\begin{tabular}{ccccccccccccc}
\hline $\mathbf{C}$ & $\mathbf{S i}$ & $\mathbf{M n}$ & $\mathbf{C r}$ & $\mathbf{N i}$ & $\mathbf{A l}$ & $\mathbf{C u}$ & $\mathbf{M o}$ & $\mathbf{V}$ & $\mathbf{N b}$ & $\mathbf{M g}$ & $\mathbf{S}$ & $\mathbf{P}$ \\
\hline 0.188 & 0.015 & 0.40 & 1.83 & 1.63 & 0.048 & 0.01 & 0.31 & 0.093 & 0.059 & 0.007 & 0.001 & 0.009 \\
\hline
\end{tabular}

Table 2. Heat treatment of $17 \mathrm{Cr} 2 \mathrm{Ni} 2 \mathrm{MoVNb}$ steel.

\begin{tabular}{ccccc}
\hline $\begin{array}{c}\text { Samples } \\
\text { Label }\end{array}$ & $\begin{array}{c}\text { Quenching } \\
\text { Temperature }\end{array}$ & $\begin{array}{c}\text { Quenching } \\
\text { Method }\end{array}$ & $\begin{array}{c}\text { Tempering } \\
\text { Temperature }\end{array}$ & $\begin{array}{c}\text { Tempering } \\
\text { Method }\end{array}$ \\
\hline 1 & $900^{\circ} \mathrm{C} \times 1 \mathrm{~h}$ & oil quenched & $180^{\circ} \mathrm{C} \times 2 \mathrm{~h}$ & water quenched \\
2 & $1000^{\circ} \mathrm{C} \times 1 \mathrm{~h}$ & oil quenched & $180^{\circ} \mathrm{C} \times 2 \mathrm{~h}$ & water quenched \\
3 & $1100^{\circ} \mathrm{C} \times 1 \mathrm{~h}$ & oil quenched & $180^{\circ} \mathrm{C} \times 2 \mathrm{~h}$ & water quenched \\
\hline
\end{tabular}

The platers $(8 \mathrm{~mm} \times 8 \mathrm{~mm} \times 8 \mathrm{~mm})$ were cut from the heat-treated samples at different temperatures, which were then polished and corroded with $4 \%$ alcohol nitric acid solution. Afterwards, the microstructure was observed using an optical microscope (OM, LEICA M165C, Barnack, Germany) and a transmission electron microscope (TEM, FEI Tecnai G20, Hillsboro, OR, USA) operating at 200 kV. An X-ray diffractometer (XRD, Cu K $\alpha$ radiation, Amsterdam, Holland) was used to identify the metallographic phase of the materials. Damage surfaces were observed with a scanning electron microscope (SEM, NOVA NANOSEM 430, Eindhoven, Holland). While the axial surface roughness of the sample was evaluated using a portable surface roughness tester (Mar Surf, M300C, Esslingen, Germany).

RCF tests were carried out by using a self-designed rolling contact fatigue testing device, the schematic of the machine is shown in Figure 1. The lower stationary sample was a disk of $\varphi 48 \times 6 \mathrm{~mm}$, the surface roughness and morphology are depicted in Figure 2. The upper rotating bearing was made of AISI52100 steel with high hardness (60 HRC) [15]. The bearing with 13 uniformity distributed balls were treated as counterpart and balls of bearing with a diameter of $2.79 \mathrm{~mm}$. The surface roughness, $\mathrm{Ra}$, was found to be less than $1.2 \mu \mathrm{m}$ [16]. The upper rotating bearing was driven by a DC motor at a speed of $1600 \mathrm{rpm}$, vertical force was applied by a hydraulic cylinder, it was measured and recorded on the computer while using a load sensor. The machine of RCF monitored the fatigue failure by the signals of vibration and torque when the vibration level exceeded the preset value, the machine would stop automatically. After each test, the bearings and lubricating oil should be replaced to ensure that the signals acquisition is not being distorted by the bearing failure or the impurities in the lubricating oil. 


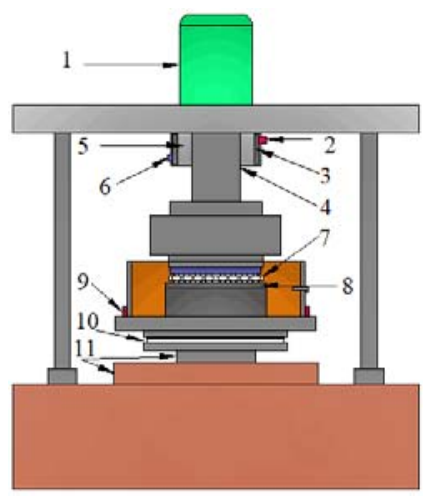

Figure 1. Schematic of the rolling contact fatigue test device. 1-DC motor, 2-Coolant outlet, 3-Coolant inlet, 4-Spindle, 5-Spindle bearing, 6-Circulating coolant chamber, 7-Bearing, 8-Specimen, 9-Heating sheet, 10-Rolling bearing, and 11-Hydraulic cylinder.
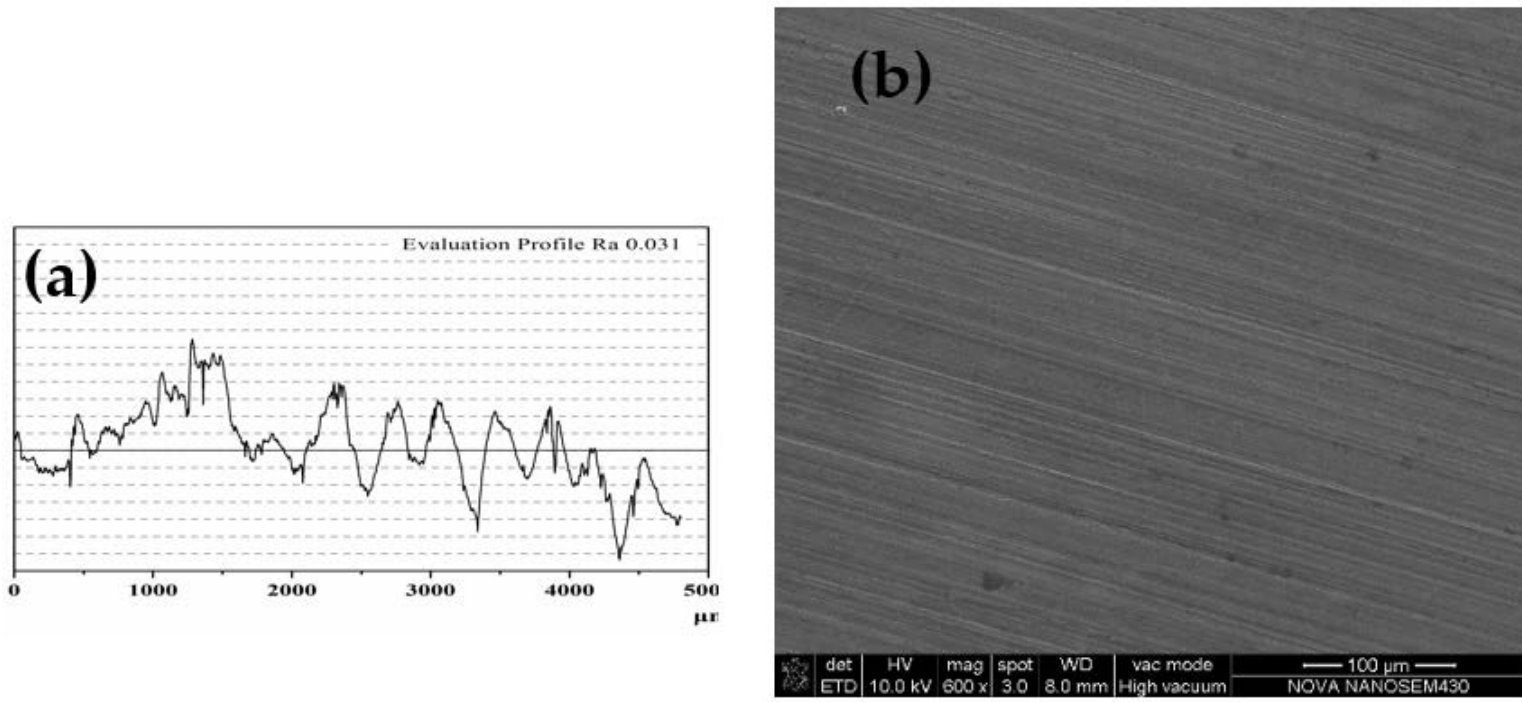

Figure 2. (a) Surface roughness and (b) morphology.

Each ball was applied $100 \mathrm{~N}$, and contact stress between the bearing and specimen was calculated by the equation, as follows:

$$
\sigma=\frac{1}{\pi} \sqrt[3]{6 F \times\left(\frac{\frac{1}{R_{1}}+\frac{1}{R_{2}}}{\frac{1-v_{1}^{2}}{E_{1}}+\frac{1-v_{2}{ }^{2}}{E_{2}}}\right)^{2}}
$$

where $\sigma$ is the contact stress; $F$ is the loading force of a single ball; $R_{1}$ is the radius of bearing ball, $R_{2}$ is the radius of the contact surface with the ball of lower stationary sample, $E_{1}$ and $E_{2}$ are the elastic modulus of bearing and specimen, respectively, $v_{1}$ and $v_{2}$ are the Poisson's of bearing and specimen, respectively.

\section{Results and Discussion}

\subsection{Effect of Quenching Temperature on Microstructure}

Figure 3 exhibits the $\mathrm{OM}$ micrograph of the $17 \mathrm{Cr} 2 \mathrm{Ni} 2 \mathrm{MoVNb}$ quenched at the temperature of 900,1000 , and $1100{ }^{\circ} \mathrm{C}$, respectively. It can be concluded from the observations that the quenching temperature has a great influence on martensite shape. Sun performed on the martensite size was determined by the martendite start temperature (Ms), the low Ms may lead to obtaining the fine martensite size [17]. Figure 4 displays the TEM microstructural structures of long and slender ferrite 
and retained austenite at each quenching temperature. The results reveal that there were much more dislocations and the austenite size increased with an increasing of the quenching temperature.
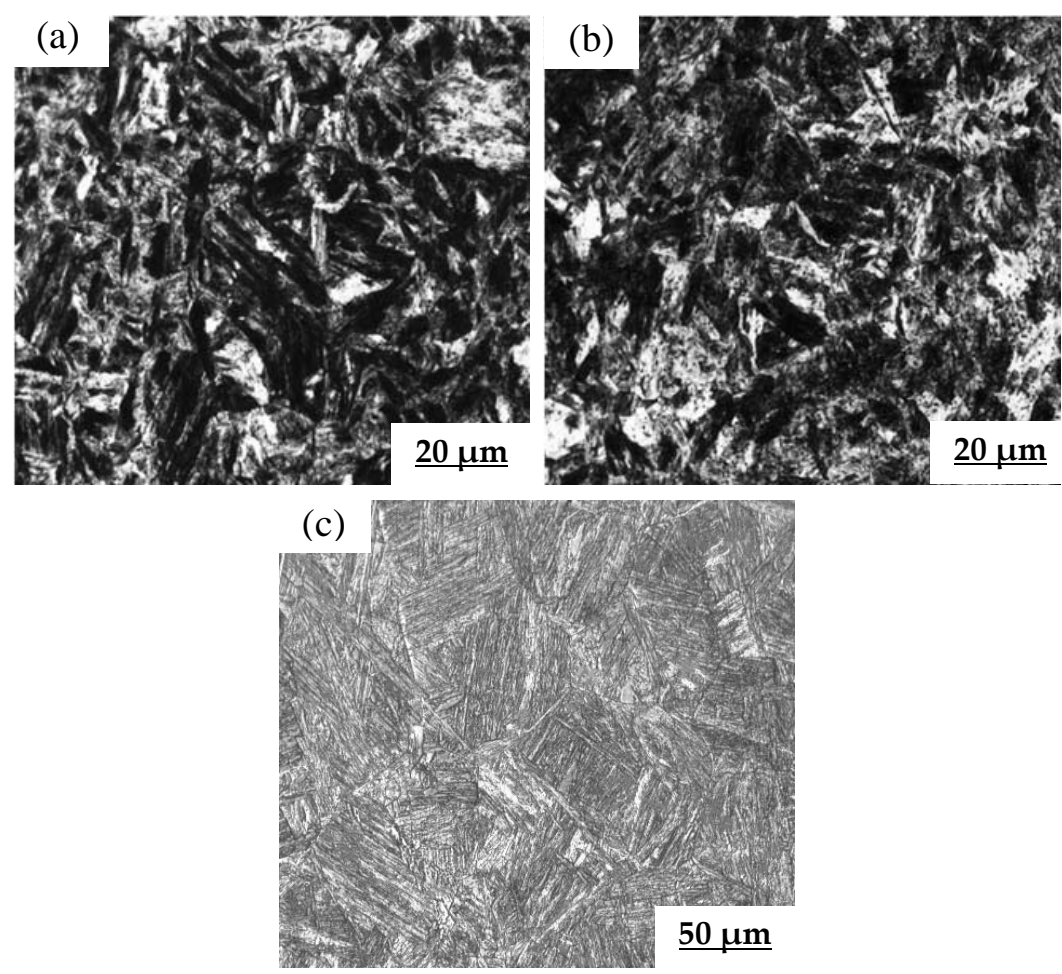

Figure 3. Optical microscopy $(\mathrm{OM})$ micrographs of $17 \mathrm{Cr} 2 \mathrm{Ni} 2 \mathrm{MoVNb}$ steel quenched at different temperatures of $(\mathbf{a}) 900^{\circ} \mathrm{C},(\mathbf{b}) 1000^{\circ} \mathrm{C}$, and $(\mathbf{c}) 1100^{\circ} \mathrm{C}$.
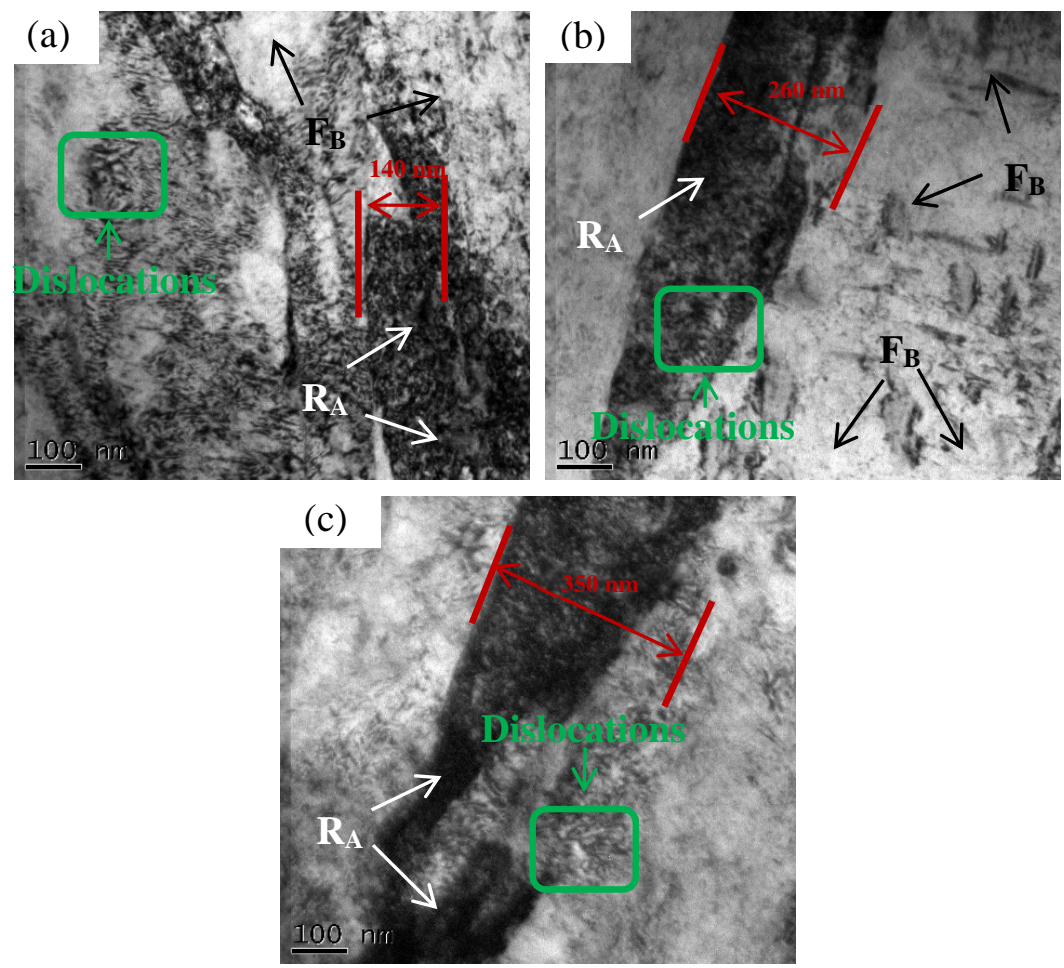

Figure 4. Transmission electron microscopy (TEM) micrographs of $17 \mathrm{Cr} 2 \mathrm{Ni2} \mathrm{MoVNb}$ steel quenched at different temperatures of $(\mathbf{a}) 900^{\circ} \mathrm{C},(\mathbf{b}) 1000{ }^{\circ} \mathrm{C}$, and (c) $1100{ }^{\circ} \mathrm{C}$. 
Figure 5 shows the X-ray diffraction (XRD) patterns. It has been reported in our previous study that the results of XRD patterns were similar and they indicate the test conditions were stable and the samples preparation was qualified [18]. It is well known that the effective methods to improve the strength in steel mainly include fine grain strengthening and precipitation strengthening [19]. Using the XRD method, the average grain size and dislocation density can be quantified. The grain size is investigated by the Scherrer equation, as follows:

$$
D=\frac{K \lambda}{\beta \cos \theta}
$$

where $D$ is the mean size of crystal, $K$ is the dimensionless shape factor, and $\lambda$ is the $X$-ray wavelength, $\beta$ is the breadth at half the maximum peak intensity, and $\theta$ is the Bragg angle (in degrees).

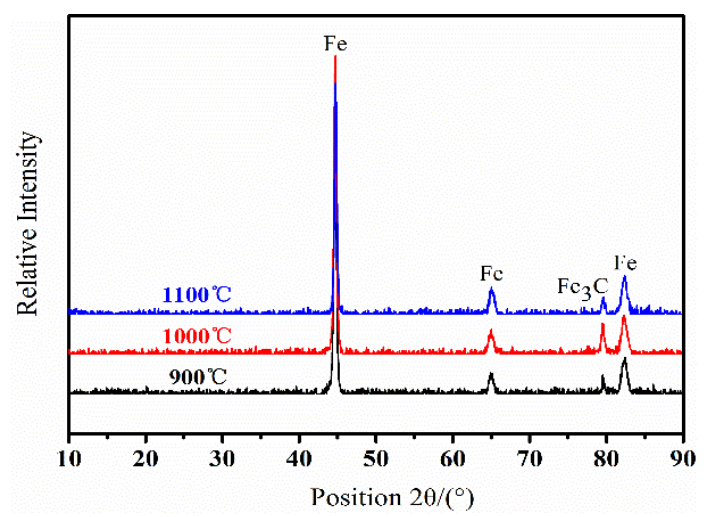

Figure 5. X-ray diffractometer (XRD) patterns of $17 \mathrm{Cr} 2 \mathrm{Ni} 2 \mathrm{MoVNb}$ steel quenched at different temperatures.

Figure $6 \mathrm{a}$ indicates that a linear relationship with 0.002 slope existed between the mean gain size and the quenching temperature from 900 to $1100{ }^{\circ} \mathrm{C}$. It also should be noted that the higher the quenching temperature, the larger the grain size. At quenching temperatures of 900,1000 , and $1100^{\circ} \mathrm{C}$, the mean grain sizes were approximately 19.63, 19.75, and $19.98 \mathrm{~nm}$, respectively.

Using the XRD method, the dislocation density can be calculated from the XRD pattern by the following equation:

$$
\rho=14.4 \frac{e^{2}}{b^{2}}
$$

where $\rho$ is the dislocation density, $e$ is the microstrain, and $b$ is Bragg's vector of dislocation in $\alpha-F e$.
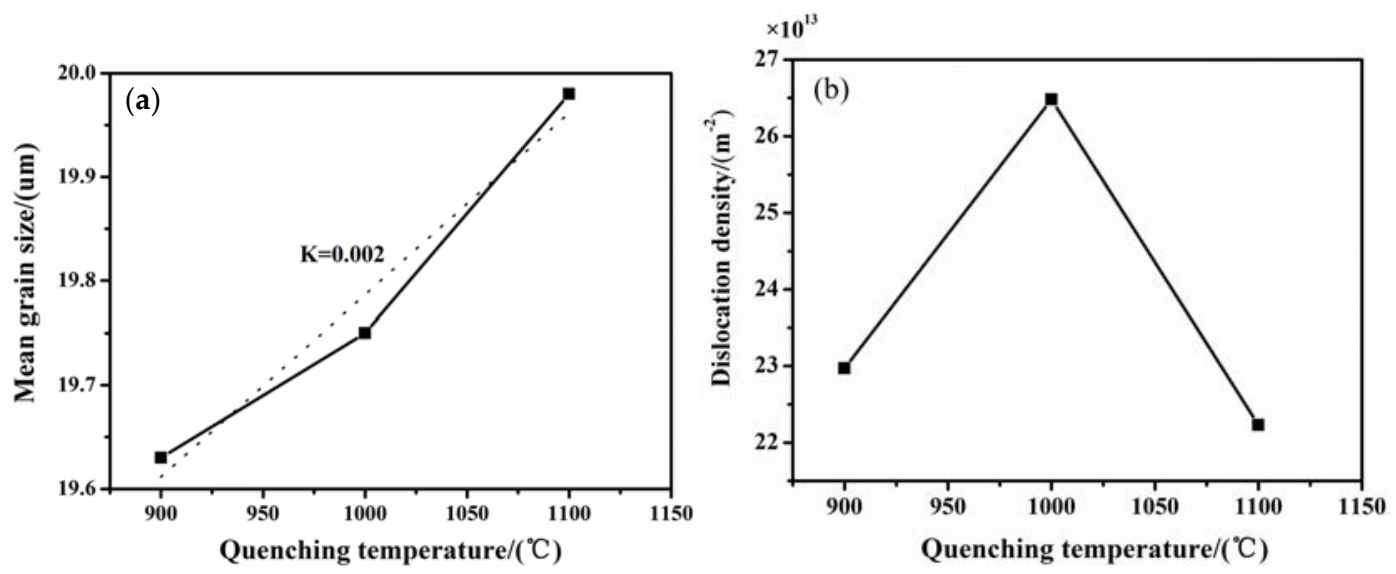

Figure 6. (a) the mean size of crystal and (b) dislocation density of samples at different quenching temperatures. 
Figure $6 \mathrm{~b}$ shows that the dislocation density increased evidently with increasing of the quenching temperature from $900{ }^{\circ} \mathrm{C}$ to $1000{ }^{\circ} \mathrm{C}$, and decreased from $1000{ }^{\circ} \mathrm{C}$ to $1100^{\circ} \mathrm{C}$. This was consistent with previous report on the effect of quenching temperature on dislocation density of bainitic steel [20]. The dislocation density of $22.97 \times 10^{13}, 26.48 \times 10^{13}$, and $22.23 \times 10^{13} \mathrm{~m}^{-2}$ at quenching temperatures of 900,1000 , and $1100{ }^{\circ} \mathrm{C}$, respectively.

\subsection{Weibull Distribution}

The Weibull distribution is widely used to assess the statistical behavior of the fatigue life $[21,22]$. In this work, two-parameter weibull distribution is used to characterize the RCF life of $17 \mathrm{Cr} 2 \mathrm{Ni} 2 \mathrm{MoVNb}$ steel. The cumulative distribution function is given as:

$$
F(N)=1-\exp \left[-\left(\frac{N}{N_{a}}\right)^{\beta}\right]
$$

where $F(N)$ is the probability of fatigue failure; $N$ is the RCF life; $\beta$ is the shape parameter of fatigue life; and, $N_{a}$ is the characterizes parameter of life.

Figure 7 shows the weibull curves of life and Table 3 shows the detail result of the fatigue life. The specified life, median life, and characteristic life of the specimen of quenched at $1000{ }^{\circ} \mathrm{C}$ were $2.11 \times 10^{6}, 2.28 \times 10^{6}$, and $2.31 \times 10^{6}$ under the contact stress of $3.2 \mathrm{GPa}$, respectively, which were larger than that of the samples quenched at $900{ }^{\circ} \mathrm{C}$ and $1100^{\circ} \mathrm{C}$. The mean life of the samples quenched at $1000{ }^{\circ} \mathrm{C}$ was 1.46 times and 1.89 times that of quenched at $900{ }^{\circ} \mathrm{C}$ and $1100{ }^{\circ} \mathrm{C}$, respectively. It is clear that the slope of the Weibull curve of quenched at $1000{ }^{\circ} \mathrm{C}$ is obviously higher than that of the other two specimens, which that indicates the distribution of the specimen data and the failure time are stable. It can be observed that the dislocation density of the samples quenched at $1000{ }^{\circ} \mathrm{C}$ was more significant when compared to that of other samples, the improved dislocation density of the samples may be attributed to the fatigue life. The specified life, median life, characteristic life, and the Weibull slope are summarized in Table 4.

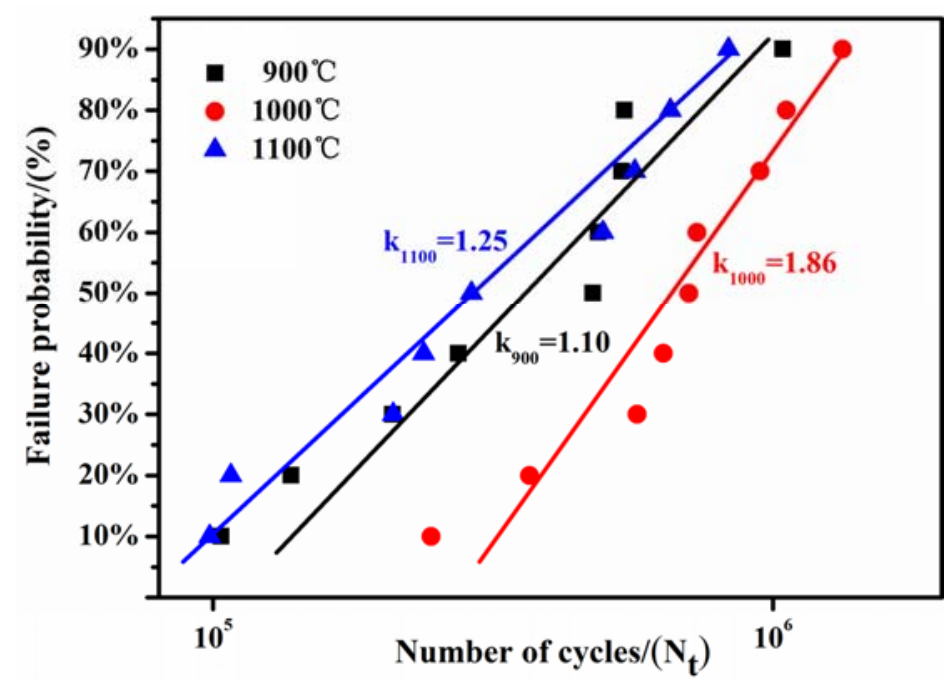

Figure 7. Weibull curves of fatigue life of $17 \mathrm{Cr} 2 \mathrm{Ni} 2 \mathrm{MoVNb}$ steel quenched at different temperatures. 
Table 3. Detail result of test date steel.

\begin{tabular}{cccccc}
\hline Samples Label & $\mathbf{9 0 0}{ }^{\circ} \mathbf{C}$ & $\mathbf{1 0 0 0}{ }^{\circ} \mathbf{C}$ & $\mathbf{1 1 0 0}{ }^{\circ} \mathbf{C}$ & $\overline{\boldsymbol{F}\left(\boldsymbol{N}_{\boldsymbol{i}}\right)}$ & $\lg \mathbf{l g}\left[\mathbf{1}-\overline{\boldsymbol{F}\left(\boldsymbol{N}_{\boldsymbol{i}}\right)}\right]^{-\mathbf{1}}$ \\
\hline 1 & 103,400 & 245,100 & 98,600 & 0.1 & -1.34 \\
2 & 137,800 & 367,300 & 107,600 & 0.2 & -1.014 \\
3 & 209,300 & 572,000 & 209,800 & 0.3 & -0.81 \\
4 & 274,300 & 637,500 & 237,800 & 0.4 & -0.654 \\
5 & 477,000 & 707,200 & 289,300 & 0.5 & -0.521 \\
6 & 487,500 & 731,900 & 497,000 & 0.6 & -0.4 \\
7 & 536,900 & 949,000 & 566,200 & 0.7 & -0.282 \\
8 & 543,400 & $1,056,800$ & 655,600 & 0.8 & -0.156 \\
9 & $1,742,000$ & $1,331,200$ & 832,600 & 0.9 & 0 \\
\hline
\end{tabular}

Table 4. Typical values of the rolling contact fatigue (RCF) life.

\begin{tabular}{cccccc}
\hline $\begin{array}{c}\text { Quenching } \\
\text { Temperature }\end{array}$ & $\begin{array}{c}\text { Mean } \\
\text { Life/105 }\end{array}$ & $\begin{array}{c}\text { Specified } \\
\text { Life/105 }\end{array}$ & $\begin{array}{c}\text { Median } \\
\text { Life/105 }\end{array}$ & $\begin{array}{c}\text { Characteristic } \\
\text { Life/105 }\end{array}$ & $\begin{array}{c}\text { Weibull } \\
\text { Plot Slope }\end{array}$ \\
\hline $900^{\circ} \mathrm{C}$ & 5.01 & 1.96 & 2.26 & 2.32 & 1.10115 \\
$1000^{\circ} \mathrm{C}$ & 7.33 & 2.11 & 2.28 & 2.31 & 1.85714 \\
$1100^{\circ} \mathrm{C}$ & 3.88 & 1.90 & 2.16 & 2.21 & 1.24786 \\
\hline
\end{tabular}

\subsection{Surface Fatigue Damage}

Figure 8 exhibits the micrographs of the damage after RCT tests. In order to compare failure mechanism at different quenching temperatures, three groups of tests with similar fatigue life were selected for observation. Figure 8 a shows the worn surface morphology of the sample quenched at $900{ }^{\circ} \mathrm{C}$ with a fatigue life of 543,400 cycles. Delamination was the main damage mode of the sample quenched at $900{ }^{\circ} \mathrm{C}$, and some spallings propagated to cracks under the influence of cyclic stress. With the increased of testing time, the local plastic strain accumulated gradually. It should be noted that the ball, contact surface of sample, and lubricating oil form a high-pressure oil chamber under the action of high-speed rotation. Those high pressure oils were squeezed into cracks and caused a great impact on the interior of the cracks.

Figure $8 \mathrm{~b}$ shows the worn surface morphology of the sample quenching at $1000{ }^{\circ} \mathrm{C}$ with a fatigue life of 572,000 cycles. A large number of fatigue pits on the contact surface, marked as arrows, some of pits have gradually expanded to the larger ones on the surface of quenched at $1000{ }^{\circ} \mathrm{C}$. It is believed that the fatigue pits can affect the roughness of the contact surface, which intensified the wear of the surface. Fatigue pits further expanded into cracks to impact on fatigue life of the specimens under stress concentration. Similar results have been reported by Fang, who concluded that micro-cracks preferentially initiate at the concave where the rough surface causes stress concentration [23].

Figure $8 \mathrm{c}$ shows the worn surface morphology of the sample quenched at $1100{ }^{\circ} \mathrm{C}$ with a fatigue life of 566,200 cycles. It indicates that the surface damage mechanism of quenched at $1100^{\circ} \mathrm{C}$ is similar to that at $900{ }^{\circ} \mathrm{C}$. However, there some sub-cracks on the subsurface in Figure $8 \mathrm{c}$, and the sub-cracks propagated to the peeling and delamination. While, the debris agglomerated in the contact surface as a moving particle plowing the surface to generate the abrasive pits.

Figure $8 \mathrm{~d}-\mathrm{f}$ show the energy dispersive $\mathrm{X}$-ray analysis (EDS) patterns of delamination and peeling. It is observed from Figure $8 \mathrm{~d}, \mathrm{f}$ that the $\mathrm{S}$ and $\mathrm{Cl}$ were found in the delamination, indicating that a bond was formed between the lubricant and the delamination under the influence of the cyclic impact of high pressure oil. However, the $\mathrm{S}$ and $\mathrm{Cl}$ were not found in the pitting in Figure 8f, indicating that the lubricating oil has good fluidity in this area. 

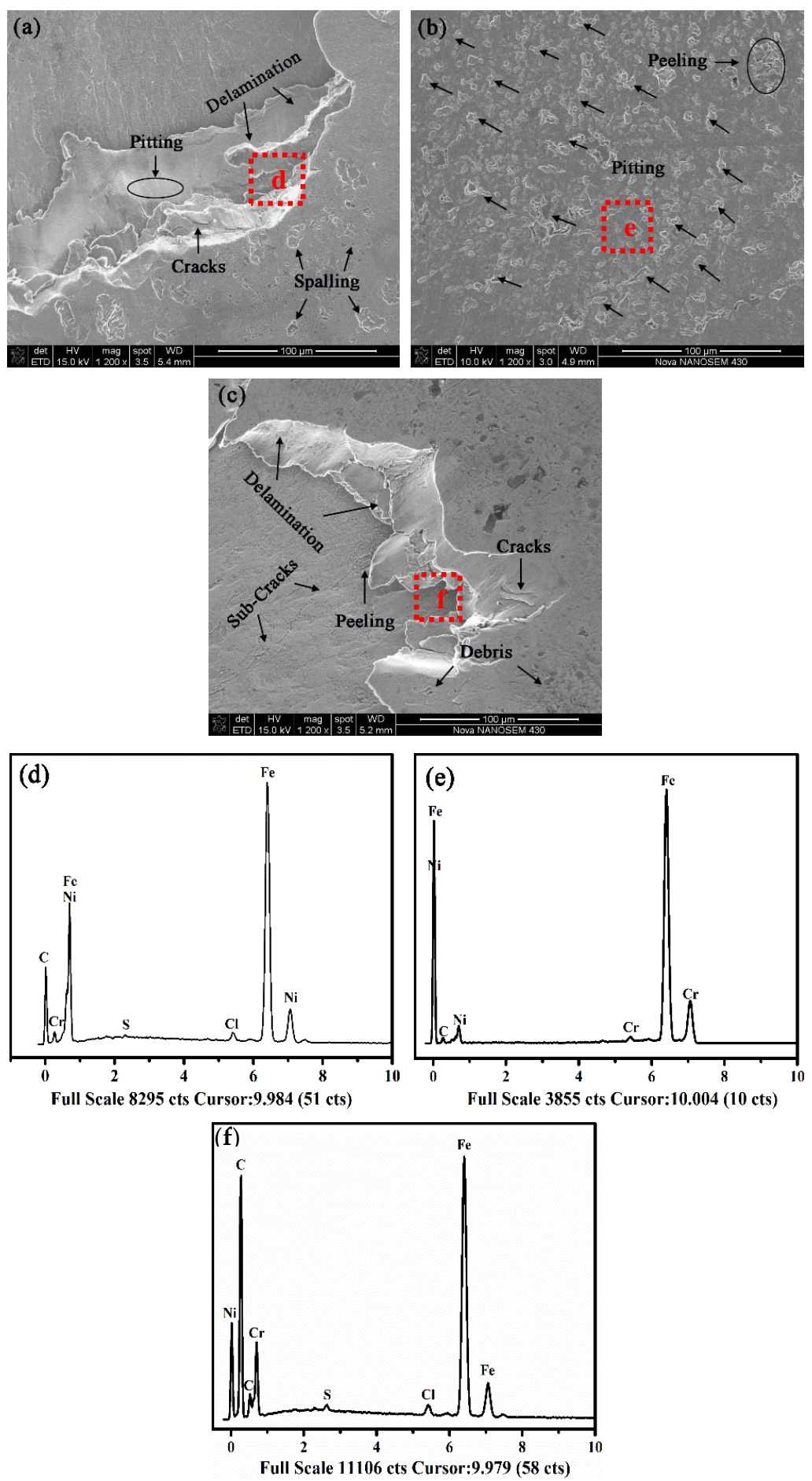

Figure 8. Typical micrographs of the damage: (a) Quenched at $900{ }^{\circ} \mathrm{C}$ contact stress $3.2 \mathrm{GPa}$ and 543,400 cycles to failure; (b) Quenched at $1000^{\circ} \mathrm{C}$ contact stress $3.2 \mathrm{GPa}$ and 572,000 cycles to failure; (c) Quenched at $1100^{\circ} \mathrm{C}$ contact stress 3.2 GPa and 566,000 cycles to failure and EDS graphs at different temperatures of (d) $900{ }^{\circ} \mathrm{C}$, (e) $1000^{\circ} \mathrm{C}$, and (f) $1100{ }^{\circ} \mathrm{C}$.

\subsection{Subsurface Fatigue Damage}

Figure 9 shows the cross-sectional subsurface damage of the samples at different quenching temperatures. It is obvious in Figure 9a that the cracks propagate parallel to the surface and the different propagation angles of cracks are growing to lamellar structure cracks. In addition, the surface and surface cracks join with each other meanwhile subsurface cracks develop to the surface of the 
sample quenched at $900{ }^{\circ} \mathrm{C}$, and the depth of plastic deformation layer in the depth direction is about $22 \mu \mathrm{m}$. Figure $9 \mathrm{~b}$ shows the SEM micrographs of the cracks of the sample quenching at $1100{ }^{\circ} \mathrm{C}$. How cracks propagate on the sample quenched at $1000^{\circ} \mathrm{C}$ is similar to the sample quenched at $900{ }^{\circ} \mathrm{C}$ under the contact stress of $3.2 \mathrm{GPa}$, The depth of plastic deformation layer in the depth direction is about $34 \mu \mathrm{m}$. Figure 9c exhibits the morphology of peeling on cross-sectional subsurface. It can be found that the subsurface cracks and lamellar structure cracks join with each other and the depth of plastic deformation layer is about $40 \mu \mathrm{m}$.
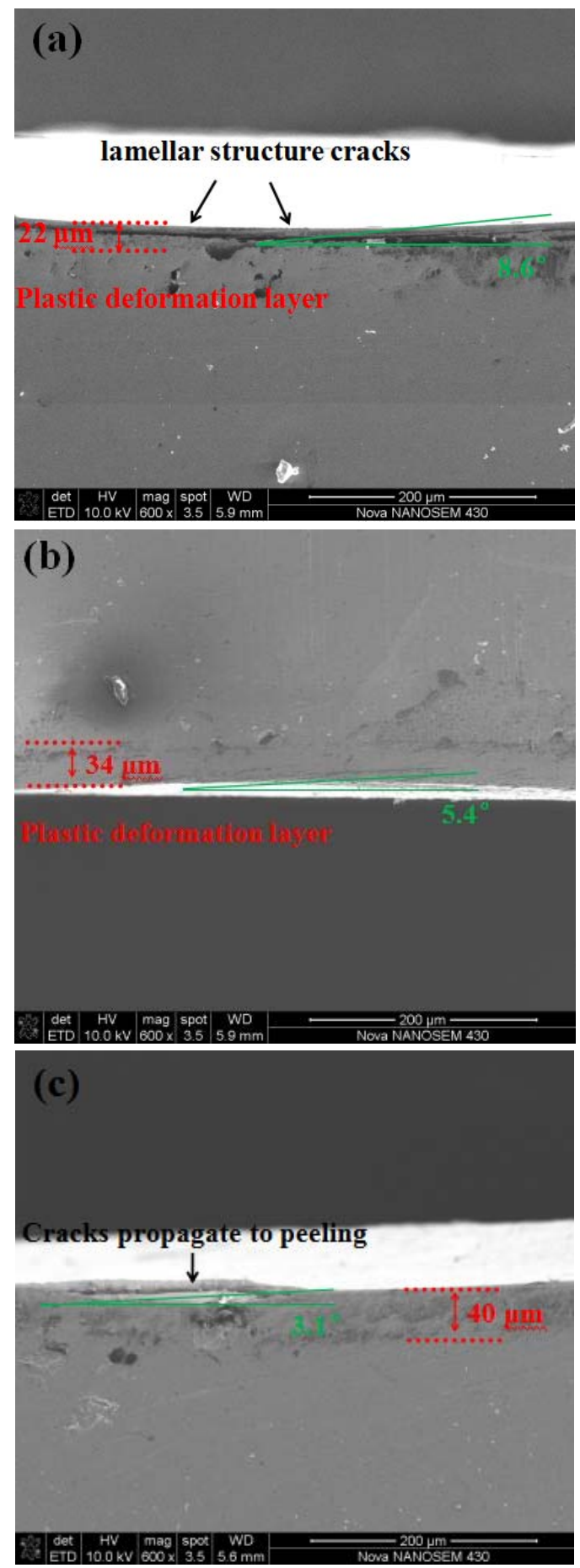

Figure 9. Micrographs of subsurface damage: (a) Quenched at $900{ }^{\circ} \mathrm{C}$ contact stress $3.2 \mathrm{GPa}$ and 543,400 cycles to failure; (b) Quenched at $1000^{\circ} \mathrm{C}$ contact stress $3.2 \mathrm{GPa}$ and 572,000 cycles to failure; and, (c) Quenched at $1100{ }^{\circ} \mathrm{C}$ contact stress 3.2 GPa and 566,000 cycles to failure. 
Moreover, the propagation angles of the sample at different quenching temperatures were about $8.6^{\circ}, 5.4^{\circ}$, and $3.1^{\circ}$, respectively, it should be noted that there was a tread of convergence between surface and subsurface cracks, small extension angles were prone to peeling. This was consistent with Ma [24], who reported the wear and damage characteristics of rail material.

It is clear that the quenching temperatures make a difference in damage mechanism of RCF cracks. Some cracks propagate along with an increasing of the quenching temperature, while cracks grow upward to the surface, and the delamination emerges under the influence of cyclic stress (Figure 8a,c). Moreover, the subsurface reveals serious lamellar structure cracks at $1100^{\circ} \mathrm{C}$ (Figure 10a), and some cracks initiate on the surface and form the peeling (Figure 10c). Quenched at $1000{ }^{\circ} \mathrm{C}$, dislocation density enhances the resistance to damage, as a result, the cracks get hard to propagate. Therefore, the lamellar structure cracks in the depth direction are the least (Figure 10b).

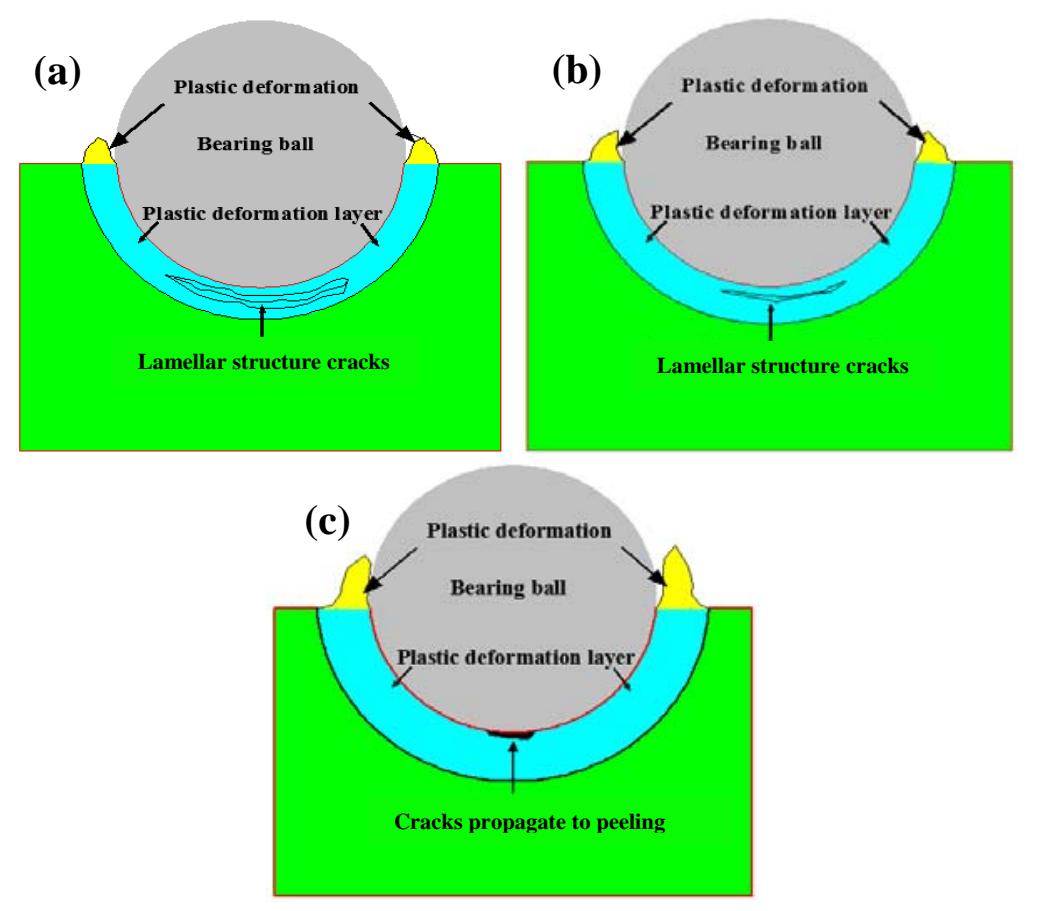

Figure 10. Schematic of fatigue damages: (a) Quenched at $900{ }^{\circ} \mathrm{C}$ contact stress $3.2 \mathrm{GPa}$ and 543,400 cycles to failure; (b) Quenched at $1000^{\circ} \mathrm{C}$ contact stress $3.2 \mathrm{GPa}$ and 572,000 cycles to failure; and, (c) Quenched at $1100{ }^{\circ} \mathrm{C}$ contact stress 3.2 GPa and 566,000 cycles to failure.

\section{Conclusions}

In this work, the effect of quenching temperatures on microstructure and rolling contact fatigue behaviors of $17 \mathrm{Cr} 2 \mathrm{Ni} 2 \mathrm{MoVNb}$ steel are evaluated. In order to address this challenge, a set of tests were conducted on $17 \mathrm{Cr} 2 \mathrm{Ni} 2 \mathrm{MoVNb}$. Based on the results, the main conclusions can be drawn, as follows:

(1). Using the XRD method, the average grain size increased while quenching temperature increased. The dislocation density increased first and then reduced.

(2). Under the contact stress of $3.2 \mathrm{GPa}$, samples at the quenching temperature of $1000{ }^{\circ} \mathrm{C}$ had the highest RCF life, the average life was $7.33 \times 10^{6}$, which was 1.46 times and 1.89 times that of $900{ }^{\circ} \mathrm{C}$ and $1100{ }^{\circ} \mathrm{C}$, respectively.

(3). The failure mechanism of the samples quenched at $1000{ }^{\circ} \mathrm{C}$ was pitting, and delamination was the main failure mode of $900^{\circ} \mathrm{C}$ and $1100^{\circ} \mathrm{C}$. The effect of lubricating oil on the pitting was mainly lubrication, and the effect on delamination was impact damage.

(4). The thicknesses of the plastic deformation layer were $22 \mu \mathrm{m}, 34 \mu \mathrm{m}$, and $40 \mu \mathrm{m}$ with the quenching temperatures of 900,1000 , and $1100{ }^{\circ} \mathrm{C}$, respectively. While cracks grew upward to the 
surface and joined with each other to form lamellar structure cracks. However, the peeling was easy to emerge when the samples quenched at $1100^{\circ} \mathrm{C}$.

Author Contributions: Both authors contributed equally to the work.

Funding: This research received no external funding.

Acknowledgments: The authors would like to thank the National Engineering Research Center of Near-Net-Shape Forming for Metallic Materials, State Key Laboratory of Smart Manufacturing for Special Vehicle as well as Transmission System and State Key Laboratory of Internal Combustion Engine Reliability for material preparation and mechanical properties testing.

Conflicts of Interest: The authors declare no conflict of interest.

\section{References}

1. Sciammarella, C.A.; Chen, R.J.S.; Gallo, P.; Berto, F.; Lamberti, L. Experimental evaluation of rolling contact fatigue in railroad wheels. Int. J. Fatigue 2016, 91, 158-170. [CrossRef]

2. Cheng, X.W.; Jiang, Z.Y.; Wei, D.B.; Hao, L.; Wu, H.; Xia, W.Z.; Zhang, X.; Luo, S.Z.; Jiang, L.Z. Effects of surface preparation on tribological behaviour of a ferritic stainless steel in hot rolling. Wear 2017, 376-377, 1804-1813. [CrossRef]

3. Gao, Y. Influence of deep-nitriding and shot peening on rolling contact fatigue performance of 32Cr3MoVA steel. J. Mater. Eng. Perform. 2007, 17, 455-459. [CrossRef]

4. Wang, X.B.; He, M.S.; Barber, G.C.; Schall, D.; Tao, C.L.; Sun, X.C. Rolling contact fatigue resistance of austempered ductile iron processed at various austempering holding times. Wear 2018, 398-399, 41-46. [CrossRef]

5. Gurudas, M.; Tewary, N.K.; Ghosh, S.K. Enhancement of mechanical properties in bainitic steel processed from different austenitization temperatures. Steel Res. Int. 2017, 2, 87-92.

6. Moravej, M.; Mantovani, D. Biodegradable metals for cardiovascular stent application: Interests and new opportunities. Int. J. Mol. Sci. 2011, 12, 4250-4270. [CrossRef] [PubMed]

7. Schinhammer, M.; Hänzi, A.C.; Löffle, J.F.; Uggowitzer, P.J. Design strategy for biodegradable Fe-based alloys for medical applications. Acta Biomater. 2010, 6, 1705-1713. [CrossRef] [PubMed]

8. Long, S.L.; Liang, Y.L.; Jiang, Y.; Liang, Y.; Yang, M. Effect of quenching temperature on martensite multi-level microstructures and properties of strength and toughness in 20CrNi2Mo steel. Mater. Sci. Eng. A 2016, 676, 38-47. [CrossRef]

9. Matlock, D.K.; Alogab, K.A.; Richards, M.D. Surface processing to improve the fatigue resistance of advanced bar steel for automotive applications. Mater. Res. 2005, 4, 453-459. [CrossRef]

10. Ma, L.; He, C.G.; Zhao, X.J.; Guo, J.; Zhu, Q.Y.; Wang, W.J.; Liu, Q.Y.; Jin, X.S. Study on wear and rolling contact fatigue behaviors of wheel/rail materials under different slip ratio condition. Wear 2016, 366-367, 13-26. [CrossRef]

11. Wang, W.J.; Guo, J.; Liu, Q.Y.; Zhu, M.H.; Zhou, Z.R. Study on relationship between oblique fatigue crack and rail wear in curve track and prevention. Wear 2009, 267, 540-544. [CrossRef]

12. Gallo, P.; Berto, F. Influence of the surface roughness on the high temperature fatigue strength and cracks initiation in 40CrMoV13.9 notched components. Theor. Appl. Fract. Mech. 2015, 80, 226-234. [CrossRef]

13. Yu, P.Z.; $\mathrm{Xu}$, B.S.; Wang, H.D. Investigation of rolling contact fatigue lives of Fe-Cr alloy coatings under different loading conditions. Surf. Coat. Technol. 2010, 204, 1405-1411.

14. Glover, D. A ball-rod rolling contact fatigue tester. In Rolling Contact Fatigue Testing of Bearing Steels; Hoo, J.J.C., Ed.; ASTM SPECIAL TECHNICAL PUBLICATION: Baltimore, MD, USA, 1982; pp. 107-124.

15. Qu, S.G.; Lai, F.Q.; Wang, G.H.; Yuan, Z.M.; Li, Q.X.; Guo, H. Friction and wear behavior of 30CrMnSiA steel at elevated temperatures. J. Mater. Eng. Perform. 2016, 25, 1407-1415. [CrossRef]

16. Wang, G.H.; Qu, S.G.; Yin, L.M.; Li, X.Q.; Yue, W. Rolling contact fatigue property and failure mechanism of carburized 30CrSiMoVM steel at elevated temperature. Tribol. Int. 2016, 98, 144-154. [CrossRef]

17. Sun, J.J.; Jiang, T.; Wang, Y.J. Effect of grain refinement on high-carbon martensite transformation and its mechanical properties. Mater. Sci. Eng. A 2018, 726, 342-349. [CrossRef] 
18. Chen, R.; Jiang, P.; Shao, X.Y.; Mi, G.Y.; Wang, C.M. Effect of magnetic field on crystallographic orientation for stainless steel 316L laser-MIG hybrid welds and its strengthening mechanism on fatigue resistance. Int. J. Fatigue 2018, 112, 308-317. [CrossRef]

19. Wang, H.B.; Wang, F.L.; Gen, H. Effect of quenching temperature on microstructure and yield strength of Q-T-treated X100Q bainitic steel. Mater. Res. Express 2018, 5, 066509. [CrossRef]

20. Zheng, C.L.; She, L.; Wang, Y.H.; Yang, Z.N.; Zhang, F.C. Rolling contact fatigue behaviors of high carbon bainitic bearing steel. J. Mech. Eng. 2017, 53, 110-117. (In Chinese) [CrossRef]

21. Walvekar, A.A.; Farshid, S. Rolling contact fatigue of case carburized steels. Int. J. Fatigue 2017, 95, $264-281$. [CrossRef]

22. Zhao, Y.Q.; Liang, H.Q. Modeling of the probabilistic fatigue S-N curves using the two parameter Weibull distribution. J. Mech. Eng. 2015, 51, 208-212. (In Chinese) [CrossRef]

23. Fang, X.; Yan, W.Z.; Gao, H.S. Finite element simulation of surface deformation of polycrystal with a rough surface under repeated load. Finite Elem. Anal. Des. 2012, 60, 64-71. [CrossRef]

24. Ma, L.; Shi, L.B.; Guo, J.; Liu, Q.Y.; Wang, W.J. On the wear and damage characteristics of rail material under low temperature environment condition. Wear 2018, 394-395, 149-158. [CrossRef]

(C) 2018 by the authors. Licensee MDPI, Basel, Switzerland. This article is an open access article distributed under the terms and conditions of the Creative Commons Attribution (CC BY) license (http://creativecommons.org/licenses/by/4.0/). 